\title{
A BÉCSI MAGYAR HÍRADÓ (1957-1980) TÖRTÉNELMI SZEREPE
}

\section{THE HISTORICAL ROLE OF THE HUNGARIAN NEWS IN VIENNA (1957-1980)}

\author{
Lipóczi-Csabai Sarolta ${ }^{1^{*}}$ \\ ${ }^{1}$ Idegennyelvi és Továbbképzési Tanszék, Pedagógusképző Kar, Neumann János Egyetem, \\ Magyarország
}

\section{https://doi.org/10.47833/2020.2.ART.005}

\section{Kulcsszavak:}

forradalom

magyar diaszpóra

emigráció

hetilap

történelem

\section{Keywords:}

revolution

Hungarian diaspora

emigration

newspaper

history

\section{Cikktörténet:}

Beérkezett: 2020. március 20.

Átdolgozva: 2020. április 20.

Elfogadva: 2020. május 20.

\begin{abstract}
Összefoglalás
A dolgozat a változó történelmi körülmények között müködö bécsi Magyar Híradó (1957-1980) c. heti- majd havilap szerepét vizsgálja a magyar sajtóirodalomban. A szerző elemzi a hetilap céljait, személyi feltételeit, emigrációs politikáját, a magyar kultúrához tartozásának kifejezését és megszünésének okait. A magyar emigráns újságírók által irt és szerkesztett hetilap fontos szerepet töltött be az ausztriai magyar menekültek tájékoztatásában a hazai és a nemzetközi helyzetröl és továbbutazási lehetőségeikről. A dolgozat írója a témához bécsi könyvtárakban végezte kutatásait.
\end{abstract}

\begin{abstract}
This paper analyses the role of the weekly newspaper Hungarian News in Vienna (1957-1980), which operates in changing historical circumstances, in the Hungarian press literature. The author analyses the goals, the personal conditions, the emigrational politics, the expression of belonging to Hungarian culture and the reasons of the cessations of the newspaper. The newspaper written and edited by Hungarian emigrant journalists played an important role in informing Hungarian emigrants in Austria about the Hungarian and international situation. The author did her research in libraries in Vienna.
\end{abstract}

\footnotetext{
* Kapcsolattartó szerző: Tel: +36205396845, E-mail: sarolta.lipoczi@gmail.com
} 


\section{Bevezetés}

Az emigráns nyugati magyar irodalom a 80-as évektől vált Magyarországon kutathatóvá és ismertté az olvasók előtt. [1, 1a] Hasonló a helyzet a nyugati magyar emigráns sajtóval is, amelynek történetében sajátos helyet foglal el a rendkívüli történelmi helyzetben létrejött Bécsi Magyar Híradó. Ezen írásunkban a heti-, majd havilap létrejöttének céljait, személyi feltételeit, emigrációs politikáját, koncepciójának átalakulását, megszűnésének okait elemezzük szövegközpontú elemzésre törekedve. Kutatásunkkal és írásunkkal hozzá kívánunk járulni a nyugati magyar diaszpóra sajtóirodalmában is tükröződő történetének jobb megismeréséhez.

\section{A lap alapításának céljai, munkatársai a magyar menekültek szolgálatában}

Az 1956-os forradalom és szabadságharc leverése után - különösen 1956 novemberében és decemberében - folyamatosan emelkedett az Ausztriába érkező magyar menekültek száma. Amikor az 1956 végén már meghaladta a százhatvanezret, az emigráns magyarokat segítő 26 segélyszervezetet felölelő Osztrák Nemzeti Bizottság és az Osztrák Szakszervezeti Tanács az ENSZ Menekültügyi fömegbízottjának támogatásával 1957. január 11-én magyar nyelvű újságot indított útjára Bécsi Magyar Híradó címmel. A lap alapítását Fritz Molden, a „Die Presse” c. osztrák napilap tulajdonosa kezdeményezte, rajta kívül Otto Molden, a Nemzeti Bizottság elnöke és Fritz Kammerer, az Osztrák Szakszervezeti Tanács fötitkára segítették létrejöttét. A nyomtatást a bécsi „Die Presse” c. napilap nyomdája végezte.

„A most megjelenő újságunknak, amelyet eljuttatunk Hozzátok, egyetlen célja az, hogy a világ eseményeinek, az itteni életnek, de általában minden, Számotokra fontos eseménynek igaz és tárgyilagos ismertetésével szolgálatára legyünk a magyar menekülteknek, akik az üldöztetések elöl segítséget és védelmet keresve a mi hazánkba jöttek." - olvasható az osztrák lapalapítók célja a Híradó első számában. [2]

A hetilap alapítóinak további szándéka a magyar menekültek tájékoztatása a nagyvilág eseményeiröl - különös tekintettel a magyarok helyzetét befolyásoló tényezökröl -, szabad, cenzúra nélküli tudósítás az ausztriai és magyarországi hírekröl, az érintettek tájékoztatása a kivándorlási lehetőségekkel kapcsolatos információkról, valamint szépirodalmi rovatával „a tábori élet” sivárságának enyhítése.

Miután az Osztrák Nemzeti Bizottság 1961-ben megszűnt, a laptulajdonos és kiadó egy évig Fritz Molden, majd 1962-től 1980-ig, a lap megszűntéig a „Bécsi Magyar Hírlapírók Köre” volt. A főszerkesztői feladatokat 1957 augusztusáig - Paál Szabolcs néven - Szöllősy Pál, 1957-58-ig Ilosvay Ferenc, 1958-59-ig Sebestyén György, 1960-tól pedig 1979-ben bekövetkezett haláláig Klamár Gyula látta el. Felelős szerkesztőként az alapítás idején Ilse Barkata, majd 1957-1968-ig haláláig - Edit Vasváry és 1972-ig Fóti József dolgozott. [3] Egy ideig szerkesztőbizottsága is müködött a lapnak. Tagjai Sebestyén György* (1964-ig), Eugen-Géza Pogány (1968-ig) és Fóti

\footnotetext{
*Sebestyén György (1930-1990) 1964-töl osztrák publicista, szerkesztő, műfordító, esszé- és regényíró, kultúraszervező. Lásd: Nyugati magyar irodalmi lexikon és bibliográfia. http://www.elib.hu/04000/04038/html/s.htm (Megj.: 2020.02. 25) 
József (1972-ig) voltak. Klamár Gyula, aki 1958-tól rovatvezetője, majd 1962-től haláláig (1979) szerkesztője volt a Magyar Híradónak, 1972-től föszerkesztőként egyedül végezte az akkor 8000 példányban megjelenő, a világ öt földrészén élö magyarokhoz eljuttatott lap szerkesztését. [4]

A szerkesztő bizottság magyarországi és külföldi tudósítókkal, levelezőkkel, írásaikat megjelentetésre elküldő írókkal, újságírókkal dolgozott. A lap munkatársai közé tartoztak még többek között - Czettler Antal, Domahidy Miklós, Fercsey János, Gosztonyi Péter, Gömöri György, Halász Ernő, Hanák Tibor, Juhász Sári, Nagy Judith, Surányi Imre, Vándor Györgyi, Varga József és Varga László. Szép számmal említhetnénk továbbá azon neves magyar írókat, költőket, akiknek művei megjelentek a lapban, de a szerzők nem tartoztak a szerkesztők sorába.

A kiadása első időszakában - 1957. jan. 11-től 1958 -ig - heti két alkalommal 100000 példányban megjelenő hírlapot egy féléven keresztül ingyen osztották az ausztriai magyar menekülttáborokban. A folyamatosan változó körülmények következtében 1958-1962-ig az újság hetilapként, ezt követően pedig 1980. január 1-ig, az utolsó számig, havonta egyszer jelent meg. Megalakulása idejétől, 1957-től 1958-ig Bécsi Magyar Híradó, majd 1958-tól fennállása végéig bécsi Magyar Híradó néven adták ki. A lap történetét bemutató írásunkban - függően attól, hogy müködésének mely időszakára vonatkozik - mindkét elnevezést használjuk. A lap fennállásától egészen a megszűnéséig vizsgált, átfogó szempontoknál a bécsi Magyar Híradó nevet alkalmazzuk.

\section{A bécsi Magyar Híradó emigrációs politikája}

Borbándi Gyula állapítja meg, hogy az ötvenhatos magyar emigráltak programja `általános elvekből és politikai szándékokból állt. Fontosabb elemei a szabad és nyitott társadalom utáni vágy, a parlamentáris demokrácia, az emberi és állampolgári jogokra és szabadságokra épül állami berendezkedés, Magyarország függetlenségére és önállóságára való törekvés, a nép önrendelkezésének joga és lehetősége." [5]

Az ausztriai magyar menekülttáborok lakóinak sorsával kapcsolatos alapvető információk iránti igények kielégítésére létrejött lap emigrációs politikáját illetően közel ált a New York-i Magyar Bizottsághoz, ami az 1956-os forradalom utáni magyarság érdekeinek ENSZ-beli és más nemzetközi fórumokon történő képviseletének hangsúlyozását, a magyarországi fejlemények és a magyar kérdés állandó figyelemmel kísérését, valamint a politikai irányzatok együttmüködését tűzte ki célul.

A lap működésének első éveiben információkkal látta el a táborok lakóit életük további alakításához, esetleg a további kivándorláshoz és beszámolt a táborok életéről és a magyar menekültek érdekében tett intézkedésekről. Tudósított a magyarországi és a nemzetközi eseményekről. A nemzetközi élet híreit - egy előírás szerint - az Osztrák Sajtóügynökség (APA) híreiböl választotta. Rendszeresen közölt írásokat Ausztria történelméröl, kultúrájáról. Első száma pl. Theodor Körner, az Osztrák Szövetségi Köztársaság elnökének 1957. január 4-én bekövetkezett halála alkalmából tartalmaz nekrológot, amelyben méltatja az elhunyt elnököt, mint katonaviselt,

\footnotetext{
Lásd: Lipóczi-Csabai Sarolta: Adalékok Sebestyén György magyar származású osztrák író, „a Duna-menti térség kentaurja" identitástudatához. In: AGTEDU: Bács-Kiskun Megyei Tudományos Fórum kötete, 2008, Kecskeméti Főiskola 100 - 106. p.
} 
politikusi pályára termett, köztiszteletben álló politikust, aki köztársasági elnökként nagy szerepet játszott abban, hogy Ausztria szabad és független ország lehessen. „Halálát a magyar nép is őszintén gyászolja, mert ... a népek barátságának és a magyar nép jobb sorsának nagy támogatóját temette el Ausztria és az egész világ." [6] Ismeretes, hogy Theodor Körner nevéhez több, a magyar menekültek befogadásával kapcsolatos rendelkezés kapcsolódik.

A bécsi Magyar Híradó által tükrözött szemléletmód középpontjában az 56-os forradalom eszméihez való hűség, az állampolgári jogok, a szabadság és függetlenség tisztelete, a magyar kultúra ápolásának és a történelmi helyzetben való eligazodás szándéka állt. Elutasította a magyarországi diktatúrát és bírálta annak kiszolgálóit. Az egykor Nagy Imre oldalán álló emigránsok - Borbándi Gyula könyvéböl kölcsönzött kifejezéssel élve - vagy egy „emberszabású szocializmus” híveiként vagy a polgári eszmények hitvallóiként, magyarként és európaiként határozták meg magukat. A szerzők Magyarország tragédiáját és a befogadó országban személyes kezdeti nehéz helyzetüket elemezve írásaikban gyakran merítettek erőt a magyar történelem nagy alakjainak gondolataiból, eszméiből, tetteiből. István király és Széchenyi eszmeiségét, gondolatait szívesen idézték. Az olvasó pontos, egyértelmű állásfoglalást tartalmazó híradást kapott a magyarországi történelmi és politikai eseményekröl. PI. Nagy Imre és társai kivégzéséről az Ausztriában a kivégzés másnapján megjelenő lap gyászkeretbe tett írásban tudósított. [7]

\section{4. „István király látomása” avagy sorskérdések napirenden}

A föszerkesztőként is közreműködő Sebestyén György - aki fiatal kora ellenére ígéretes magyarországi újságírói és szerkesztői pályát tudhatott maga mögött - és llosvay Ferenc nagyhatású írásokban fogalmazták meg az 56-os emigránsokat foglalkoztató legfontosabb kérdéseket. llosvay Ferenc: Miért is menekültünk? (BMH, 1957. okt. 15.) [8] és Rabok legyünk vagy szabadok?, valamint Sebestyén György „Európa, hol vagy?” című (1957. okt. 25.), [9] a forradalom első évfordulójára megjelentetett írásaikban pl. az együttérzést a bebörtönzöttekkel, a forradalomért hozott áldozat értelmét, a magyarok hőstettét európaiságukért, Európa felelősségét és az európaiságba vetett hitet emelik ki. „Magyarnak s európainak lenni egyszerre: földrajzi helyzetünknek, történelmünknek és minden lelki rezdülésünknek következménye; s ezért az egyszerü tényért a magyarságnak fegyverhez kellett nyúlnia.” [10] Évzáró összegezés és újévi programadó Sebestyén György:„Újévi beszélgetés Széchenyivel” c. írása [11] „A szétszórt nemzet milliós közösségét a nemzeti ünnepek kötik össze."- állapítja meg Sebestyén „István király látomása” [12] címmel publikált vezércikkében, amellyel a nemzetet fenntartó történelmi tudatot kívánja erősíteni az államalapító bölcs felismeréseit idézve.

A fenti megállapításokat, amelyeket a lapban megjelent írások alapján fogalmaztunk meg, Borbándi Gyula már idézett könyvében az alábbi mondataival jellemzi: „A forradalmat követő években a régi és új emigránsokat nemcsak a jövőben követendő utak és célok foglalkoztatták, de az is, mi történt végső soron 1956 októberében-novemberében és milyen tanulságok vonhatók le a magyarországi eseményekből.” [... ],„Sok magyar politikus és közíró elfeledkezni látszott arról, hogy a nagyhatalmak politikáját sajátos hagyományok, célok, érdekek szabják meg és a magyar törekvések méltánylására csak akkor lehet számítani, ha ezekbe beleillenek." (13)

\section{A magyar kultúrához tartozás kifejezése}


A bécsi Magyar Híradó fontos színtere volt a magyar szellemiséghez, kultúrához tartozás kifejezésének. Színvonalas válogatást közölt a magyar irodalom kincseiböl, köztük emigrált költők és írók műveiből. A szerkesztő tudatosan nyúlt pl. Balassi, Kölcsey, Arany, Ady, Karinthy verseihez. (PI. Arany János: Széchenyi emlékezete c. verse az 1958. június 28-i számban Nagy Imre gyászolására jelent meg."Te sem haltál meg, népem nagy halottja! ...Egy nemzet gyásza nem csak leverö: Nép, mely dicsőt, magasztost, i g y magasztal, Van élni abban hit, jog és erö!') A lap tükrözte a kortársak tiszteletét Illyés Gyula, Németh László és Kodály Zoltán iránt. Szerepet vállalt a Magyarországon betiltott írások közlésében és az emigrációban élő alkotók - pl. Sulyok Vince, Parancs János és Tollas Tibor költők, Monoszlóy Dezső, Márai Sándor írók - műveinek bemutatásában. Megállapítható, hogy az emigráció első éveiben írt versekben az aggodalom az otthon maradt társakért és az elhagyott haza sorsáért, a honvágy, a haza elvesztése iránti fájdalom és egyben a szabadság megtalálásának kifejezése dominált. („Európa! Fájdalmas kincs vagy te magyar üldözöttnek. Jánosfalvy Albert (Svájc): Megtalált Európa; [14] „Életem értelmének tudlak, drága szabadság!"(Sulyok Vince / Oslo: Dagály c. verse. [15] BMH, 1958. dec. 6.) Később e gondolatokhoz társult az integrációval járó nehézségek, a nyelvváltás, a „kettős élet” ábrázolása. Az irodalmi rovatok messze túlhaladták a lap első számában a szépirodalmi művek közlésével vállalt célt, a „tábori élet” sivárságának enyhítését.

A lap erősítette a szolidaritás és az összetartozás érzését az ausztriai és a világ más országába került magyar emigránsokkal. Rendszeresen közölt leveleket és publicisztikai írásokat emigráns alkotóktól, sorstársaktól (pl. Gömöri György, Határ Győző) vagy ismeretlen, együtt érző levélíróktól. A svájci Magyar Híradó egy ideig a bécsi Magyar Híradó melléklete volt. A szerkesztőség nagy hangsúlyt fektetett a forradalom nemzetközi visszhangjának bemutatására is (pl. Albert Camus, Hugh Seton-Watson, Luigi Fossatti írásai). Beszámolt a Magyar Írószövetség aktuális helyzetéröl, felháborodott hangon tájékoztatott a magyarországi írók letartóztatásáról.

A magyar kultúra eseményeiröl, eredményeiről a világban, pl. emigráns szerzők munkáinak megjelenéséről, színházi előadásokról, hangversenyekről számtalan tudósítást olvashatunk a Híradóban. Így pl. rendszeres beszámolót találhatunk hasábjain az emigráns zenészekböl álló Philharmonia Hungarica zenekar nagysikerű szerepléseiről, a sportesemények között Puskás Ferenc sikereiről. Foglalkozott a lap az emigrációban élők nyelvromlásának jelenségével is. [16]

A bécsi Magyar Híradó ugyanakkor nem olyan radikális lap volt, mint az ugyancsak 1957-ben Bécsben alapított és 1963-ig Bécsben szerkesztett és Münchenben kiadott Nemzetör, amely Kecskési-Tollas Tibor főszerkesztő közremüködésével - a „Szózat” első sorát választotta mottóként és „A magyar szabadságharcos írók lapja külföldön” önmeghatározást használta. "A dunamenti Európa és az otthoni élet problémái, a világ eseményeinek kitünő összefoglalása egyaránt szerepel hasábjain..."-írta a bécsi Magyar Híradóról Bányai Zoltán. [17]

\section{A lap funkciója a megváltozott történelmi körülmények között}

A bécsi Magyar Híradó funkciója a 60-as évek elejétől az emigránsok helyzetének változásával - a hidegháborús viszonyok között - módosult. A menekülttáborok lakóinak száma folyamatosan csökkent, a menekülteket befogadták a világ különböző országai Ausztria felhívására, megkezdődött integrációjuk a világ különböző országaiban. Erősödtek a hivatalos és személyes kapcsolatok Ausztria és Magyarország között. 1963-ban újra megnyílt a bécsi Collegium 
Hungaricum. A hetvenes évek elejétöl kezdetét vette Magyarország nyugati kapcsolatainak javulása. A magyarországi enyhülés nagy hatással volt az Ausztriában élő emigránsokra. Megkönnyítette az ebben az időszakban már osztrák állampolgárként történő közeledésüket volt hazájukhoz. Magyarországról azonban sokáig a kifogástalan magaviseletü, az emigráció munkájában részt nem vevő állampolgárok utazhattak Ausztriába, ők is vízummal.

Az emigrált magyarokban természetesen továbbra is sok kétség merült fel a magyarországi viszonyokat illetően és nem tudták elfogadni a magyarországi helyzetet. Abban hittek, hogy kritikai magatartásuk befolyásolni tudja az otthon történteket. A kételyeknek a bécsi Magyar Híradó is hangot ad. [18] De müködési terepe a politikai színtérröl egyre inkább a magyar kultúra ápolásának területére helyeződött át. A nyugati magyarság helyzetét ábrázoló írások a magyarság, mint szellemi, kulturális közösség müködésére helyezik a hangsúlyt a bécsi Magyar Híradóban is: az anyanyelv, a magyar hagyományok, a magyar kultúra megőrzésének, ápolásának, a magyar nemzeti identitás átélésének igényére és az ezekkel kapcsolatos tudatos szerepvállalásra. A lap ennek megfelelően - beszámolt pl. a Bécsben 1960-ban Szépfalusi István vezetésével megalakult Bornemisza Péter Társaság munkájáról, a magyar szellemiség egységét megvalósítani szándékozó programjairól, az 1964-ben létrejött Európa Club magyar kulturális összejöveteleiröl és a Bécsi Magyarok Kultúregyesületének tevékenységéről. Hasonlóképpen tájékoztatott a nyugat-európai és tengeren túli magyar kulturális egyesületek és társaságok, irodalmi mühelyek tevékenységéröl, folyóiratok - pl. a párizsi Magyar Mühely (1962) és az Új Látóhatár (1962) - kiadásáról.

A bécsi Magyar Híradó a tájékoztatás e folyamatában is fontos szerepet játszott, de az anyagi támogatás hiánya és a lap csökkenő példányszáma következtében egyre nagyobb nehézségekkel küzdött. Klamár Gyula, aki 20 évig a lap főszerkesztője volt, hosszú időn keresztül fenn tudta tartani a Híradót. Személyisége meghatározta annak jellegét. Klamár Gyula „Szeizmográfszerü érzékenységgel reagált a legkisebb hírre is, amely a magyar olvasót érdekelhette." [19]

\section{A lap megszűnése, új lap alapítása}

A lap teljesítette történelmi feladatát. Eredeti célkitüzéseinek megfelelt, majd átalakult a megváltozott körülmények hatására. Fennmaradása ilyen hosszú időn keresztül - a kialakult anyagi nehézségek mellett - szerkesztőinek köszönhetö.

A kortársak visszaemlékezései szerint Klamár Gyula főszerkesztőt humanizmus, magyarságszeretet, az európai kultúrához való ragaszkodás és a politikai tolerancia jellemezte. [20] Egy pályatárs megállapítása szerint „Klamár nem magyar politikai lapot akart kiadni, hanem olyan magyar újságot, mely csak kényszerüségböl lát itt napvilágot, melynek a jelen politikai konstellációban a külföld a legmegfelelöbb megjelenési hely, hiszen csak így tarthatja meg függetlenségét, pártonkívüli jellegét és egyensúlyra törekvő objektivitását.” [20] (Hanák Tibor, BMH 1980.jan.1.)

A Magyar Híradót elemző legújabb szakirodalom szerzője tanulmányában rámutat, hogy a lap nem csak a magyar emigránsok helyzetét tükrözte, hanem tartalmilag, esztétikailag és stílusát tekintve a befogadó osztrák társadalom elvárásainak is megfelelt. Ezért is vonta magára az Állambiztonsági Szolgálatok figyelmét.(21) 
A bécsi Magyar Híradó 23 éves történetét felidéző tanulmányunkat a főszerkesztő Klamár Gyula szerepét jellemző gondolattal zárjuk, amely a lap utolsó számában jelent meg: „Egy oldódó, biológiailag és eszmeileg is gyengülő emigrációban a toleráns európai magyarság őrzőjének lenni nem könnyü feladat." [22]

A lap megszünését követöen jött létre az Ausztriai Magyar Egyesületek és Szervezetek Központi Szövetségének lapja, a napjainkban is müködő Bécsi Napló Dr. Hanák Tibor, majd Dr. Deák Ernő főszerkesztő irányításával.

\section{Köszönetnyilvánítás}

Köszönjük a Magyar Ösztöndíj Bizottságnak, hogy támogatta kutatásunk elvégzését, valamint az Ausztriai Magyar Egyesületek és Szervezetek Központi Szövetsége volt elnökének, Dr. Deák Ernőnek, hogy a havilap rendelkezésre bocsátásával segítette munkánkat.

\section{Irodalomjegyzék}

[1] Béládi Miklós, Pomogáts Béla, Rónay László: A nyugati magyar irodalom 1945 után. Gondolat Kiadó, Budapest, 1986. 1-327.p.

[1a] Journal Article published 1987 in World Literature A nyugati magyar irodalom 1945 után by Miklós Béládi, Béla Pomogáts, László Rónay Review by: George Gömöri DOI: 10.2307/40143216

https://www.jstor.org/stable/40143216

[2] Bécsi Magyar Híradó, 1957. jan. 11. 1. o. (Ausztriai Magyar Egyesületek és Szervezetek Központi Szövetsége - a továbbiakban: AMESZKSZ - Könyvtára, Bécs, Schwedenplatz 2.

[3] Borbádi Gyula: Nyugati Magyar Irodalmi Lexikon és Bibliográfia. Hitel, Budapest, 1992. AMKSZK http://mek.niif.hu/04000/04038/html/ (Letöltés: 2020.01.25.)

[4] Juhász Sári írása; Bécsi Magyar Híradó, 1980. jan. 1. (AMESZKSZ)

[5] Borbándi Gyula: A magyar emigráció életrajza 1945-1985. Európa Kiadó, Budapest, 1989. 298.o.) (AMESZKSZ) https://mek.oszk.hu/03400/03472/html/ (Megtekintés: 2020.02.10.)

[6] Bécsi Magyar Híradó, 1957. január 11. 1. o. (AMESZKSZ)

[7] Bécsi Magyar Híradó, 1958. június 28. 1. o. (AMESZKSZ)

[8] Bécsi Magyar Híradó, 1957. okt. 15. 1. o. (AMESZKSZ)

[9] Bécsi Magyar Híradó, 1957. okt. 25. 1. o. (AMESZKSZ)

[10] Bécsi Magyar Híradó, 1957. okt. 25. 1. o. (AMESZKSZ)

[11] Bécsi Magyar Híradó, 1957. dec. 26. 1. o. Osztrák Nemzeti Könyvtár / (AMESZKSZ)

[12] Bécsi Magyar Híradó, 1962. aug. 15. 1. o. (AMESZKSZ)

[13] Borbándi Gyula: A magyar emigráció életrajza 1945-85.Európa Kiadó, Bp., 1989. 254. o. (AMESZKSZ) https://mek.oszk.hu/03400/03472/html/ (Megtekintés: 2020. 02.12.)

[14] Bécsi Magyar Híradó, 1958. május 7. (AMESZKSZ)

[15] Bécsi Magyar Híradó, 1958. dec. 6. (AMESZKSZ)

[16] Gyermekek a német nyelvtengerben; Bécsi Magyar Híradó, 1959. júl. 1. (AMESZKSZ)

[17] Bécsi Magyar Híradó, 1957. júl. 26. (AMESZKSZ)

[18] Borbándi Gyula: A magyar emigráció életrajza 1945-85.Európa Kiadó, Bp., 1989. 254. o. (AMESZKSZ) https://mek.oszk.hu/03400/03472/html/ (Megtekintés:2020. 02. 20.)

[19] Juhász Sári, Bécsi Magyar Híradó H, 1980. jan. 1. (AMESZKSZ)

[20] Gosztonyi Péter, Bécsi Magyar Híradó, 1980. jan.1. (AMESZKSZ)

[21] Károly Kókai: Migration und Literatur in Mitteleuropa. Komparatitische Studien. A No Press Publications 2018 p.82.

[22] Név nélkül: Búcsú az olvasótól, Bécsi Magyar Híradó, 1980. jan.1. (AMESZKSZ) 